\title{
Değerler Eğitimi Bağlamında Siirt Menkıbeleri
}

\author{
Siirt Hagiography in Terms of Values Education
}

\author{
Rezan Karakaş* \\ Erdem Akın**
}

\section{Özet}

Türkler, sosyo-kültürel süreç içerisinde bazı davranış kalıplarına olumlu anlamlar yükleyerek aynı zamanda bu davranış kalıplarının inşasına ve korunmasına önem vermişlerdir. Toplum tarafından onaylandığı için tekrarlanarak kalıp haline gelen davranışlar, geçen yüzyıllar içerisinde soyut anlam kazanarak birer değer haline gelmiştir. Dolayısıyla sosyo-kültürel hayatın bir yansıması olan edebi ürünlerde bu değerlerin işlenmesi kaçınılmaz bir hal almıştır.

Anonim halk edebiyatı ürünlerinden olan menkıbelerde de muhataba verilmek istenen mesaj, kuru bir ileti olmanın dışında, halkın kültür kodlarına işlenmiş değerlerdir. Toplumlar, geleceklerini sağlıklı bir şekilde oluşturabilmek için bu değerleri gelecek nesillere aktarma ihtiyacı duyarlar. Bu çalışmada, Siirt menkıbeleri, değer eğitimi açısından ele alınmış, Siirt ilinde derlenmiş olan menkıbelerde, değerlerin nasıl ve ne sıklıkta işlendiği tespit edilmeye çalışılmıştır. Araştırmada nitel araştırma yöntemlerinden metin inceleme yöntemi kullanılarak Siirt menkıbelerinde bulunan değerler tespit edilmiştir. Araştırmanın veri toplama kaynağını "Siirt Menkıbeleri ve Türbe Ritüelleri” adlı kitapta yer alan toplam doksan menkıbe oluşturmaktadır. Verilerin analizinde betimsel analiz yaklaşımı kullanılmıştır. İnceleme; Rokeach’ın değer sınıflandırması çerçevesinde yapılmış, ulaşılan sonuçlar, değer eğitimi açısından yorumlanmıştır. Sonuç olarak; kendini kontrol

\footnotetext{
* Doç. Dr., Siirt Üniversitesi Eğitim Fak. Türkçe Eğitimi Bölümü. rezankarakas@hotmail.com

** Araştırma Görevlisi, Siirt Üniversitesi Fen Edebiyat Fak. Türk Dili ve Edebiyatı Bölümü. erdemakin19 @gmail.com
} 
edebilme, yardımseverlik, geniş görüşlü olmak ve bilgelik gibi vasıta ve gaye değerlerin gelecek nesillere aktarımında menkıbelerin kullanılabileceği görülmüştür.

Anahtar sözcükler: Siirt; menkıbe, değer eğitimi, Türk kültürü, halkbilimi

\section{Abstract}

In the social and cultural process, the Turks put positive meanings on some behavioral patterns and they give importance to the construction and preservation of these behavioral patterns. The behaviors that have become repetitive as they are endorsed by the society have become values in the last centuries by gaining abstract meaning. Therefore, these values have become inevitable in literary products which are a reflection of social and cultural life.

Hagiographies as an anonymous folk literature genre the message that is required to be given to the reader is not only a prosaic message, but also values that are processed into the cultural codes of the people. Societies need to convey these values to future generations in order to be able to create their future in a healthy way. In this study, Siirt hagiographies were discussed in terms of value education. In the hagiographies collected in Siirt province, it was tried to determine how and how often the values were processed. In the study, the values in the Siirt hagiographies were determined by using the textual analysis method of qualitative research methods. The data collection source of the study is the total ninety hagiographies in the book "Siirt Hagiographies and Tomb Rituals". A descriptive analysis approach was used in the analysis of the data. The study was conducted within the framework of Rokeach's value classification and the results achieved were interpreted in terms of value education. As a result, it has been seen that the instrumental and terminal values such as self-control, benevolence, broad-mindedness, and wisdom can be transmitted to future generations through hagiographies.

Keywords: Siirt, hagiography, education, value education, Turkish culture, folklore

\section{Giriş}

Değer sözcüğü, Türkçe sözlükte "bir şeyin önemini bilmeye yarayan soyut ölçü, karşılık, kıymet” şeklinde tanımlanmıştır (Türkçe Sözlük 2005: 483). Değer sözcüğü kavram olarak ilk kez Znaniecki tarafından kullanılmıştır. Sözcük Latince kökenli "güçlü olmak" veya "değerli olmak" anlamına gelen "valera" kelimesinden türetilmiştir (Aktürk 2012: 147).

Değer kavramı; felsefe, psikoloji, sosyoloji, matematik, iktisat gibi birçok bilim dalında sıklıkla kullanılan kavramlardan biridir. Birey davranışlarını yönlendiren güç olmaları yönüyle psikolojiyi, toplumsal bir olgu olmaları yönüyle sosyolojiyi ve kültürden kültüre değişebilen bir yapı arz etmeleri ile de antropolojiyi ilgilendirmektedir (Kaymakcan 2010: 10). Değerlerin toplumsal olgu olarak kültürden kültüre değişebilen bir yapı olması, tamamen toplumda kabul görüp görmemesine bağlı olarak değişir. Bu durumu Özbay şu şekilde ifade eder: "Değerler bir toplumun çoğunluğu tarafından kabul gören, inanılan ve korunmaya çalışılan davranış şekilleridir” (Özbay 2002: 114).

Değerlerin genel niteliklerini inceleyecek olursak Bilsky ve Shwartz şu özellikleri sıralamıştır: 1. Kavram ve inançlardır. 2. Arzulanır amaç ifadeleri veya davranışlardır. 
3. Belli durumların üstünde ve dışındadırlar. 4. Olayların ve davranışların seçimine rehberlik ederler. 5. Göreli önemlerine göre sıralanırlar (Uyanık Balat 2012: 9).

Topluma yön vermenin ilk ve en önemli boyutu eğitimdir. Toplum; gideceği istikameti, bünyesinde bulunan değerleri, genç nesillere aktararak belirler. Bu sebepledir ki içerisinde birtakım değerler barındırmayan bir eğitim düşünülemez. Bu bağlamda değerleri, eğitimin yapı taşları olarak düşünmek yanlış olmayacaktır.

Avrupa ve Amerika'da değerler eğitiminin nasıl yapılması gerektiğine yönelik yapılan önemli ve nitelikli çalışmalar, ülkemizde de ses getirmiş, değerler eğitimiyle ilgili pek çok çalışmanın önü açılmıştır. Bu konuda Milli Eğitim Bakanlığı da harekete geçmiş, 2010 yılında İstanbul'da "Uluslararası Değerler Eğitimi Konferansı" düzenlemiştir. 2010 yılında gerçekleştirilen 18. Milli Eğitim Şurası’nın da önemli konu başlıklarından biri değerler eğitimi olmuş, değerlerin tüm bireylere aktarılması noktasında tavsiye kararı alınmıştır (Güven 2014: 229).

Değer kavramı, birçok alanla irtibatlı olduğu ve oluşum süreci farklı açılardan incelendiği için birden fazla değer sınıflandırılması yapılmıştır. Değerler arasında keskin ayrımlar yapmak mümkün olmasa da özelliklerine, işlevlerine göre bazı sınıflandırmalar yapılabilmektedir (Güler 2015: 16). Değerleri bilimsel açıdan sınıflandıran araştırmacılara Spranger, Rokeach ve Schwartz örnek olarak verilebilir. Bu çalışma, Rokeach’ın sınıflandırması temelinde şekillendirilmiştir. Rokeach, 1973 yılındaki çalışmasına göre değerleri şu şekilde sınıflandırmıştır (Şen 2007: 10):

1. Gaye Değerler: Aile güvenliği - Barış içinde bir dünya - Başarılı olma - Bilgelik Dinî olgunluk - Eşitlik - Gerçek dostluk - Güzellikler dünyası - Heyecan verici bir hayat - İç huzur - Mutluluk - Kendine saygı - Gerçek dostluk - Özgürlük - Rahat bir hayat Sosyal kabul - Ulusal güvenlik - Zevk.

2. Vasıta Değerler: Bağımsız olma - Affedici olma - Cesaretli olma - Dürüst olma Entelektüel olma - Geniş görüşlü olma - Hirslı olma - İtaatkâr olma - Kendini kontrol edebilme - Nazik olma - Kendine hâkim olma - Mantıklı olma - Neşeli olma - Sevecen olma - Sorumluluk bilincinin olması - Temiz olma - Yardımsever olma - Yaratıcı olma.

Değerler eğitimi oldukça hassas bir süreçtir. Belli bir yaştaki bireylere önceden programlanmış hedefleri başarıyla aktarmak, etkili yöntemleri kullanmayı gerektirir. Bu etkili yöntemlerden biri olduğuna inandığımız menkıbe anlatıcılığında, ders alma ve hisse çıkarmayı esas alan bir eğitim tarzı söz konusudur.

Bireyin eğitimi ailede başladığı gibi değer eğitimi de ailede başlar. Çekirdek tipi bir ailede çocuğun ilk öğretmenleri anne ve babasıdır. Geniş aile tipinde bu öğretmen kadrosu; babaanne, anneanne veya dedenin de katılımıyla genişlemektedir. Çocuğun aile içinde almış olduğu "değer eğitimi” öncelikli olarak onun aile içindeki tutum ve davranışlarını şekillendirir. Bir süre sonra okul hayatına ve sosyal hayata girecek olan çocuğun sosyalleşmesine katkı sunacak öğretmen kadrosu daha da genişleyecektir. Kaçınılması imkânsız olan bu durum, bireyde zaman zaman farklı tutum ve davranışlara sebep olabilmektedir. Ancak çocuğun bütün bunları görmesi ve yaşaması, onun sosyalleşmesi bağlamında bir zorunluluktur.

Toplumun huzur içinde yaşaması, o topluluğun uzun yıllar boyunca benimsemiş olduğu değerlerin özümsenmesi ile gerçekleşir. Farklı dil, din, düşünce ve ideolojileri 
benimsemiş bireylerin aynı toplum içinde bir birliktelik oluşturması, ancak ortak değerlere sahip olmakla mümkündür.

Bir kişinin herhangi bir değere sahip olup olmadığı veya ne ölçüde sahip olduğu, ancak o toplumun diğer üyelerinin durumunun analiz edilmesiyle anlaşıllır. Her ne kadar evrensel değerlerden bahsetmemiz mümkünse de bireyin sahip olduğu değerler, çoğunlukla içinde yaşanılan toplumun benimsediği değerler kapsamında ele alınır. Kısacası bir değer bireyin, toplumun diğer üyeleriyle ilişkisi neticesinde ortaya çıkar.

Siirt menkıbelerindeki değerleri belirlemeye başlamadan önce değerlerin işlevlerine değinmek gerekir. Elbette, bütün değerlerin toplum nezdinde ayrı ayrı işlevleri vardır. Gökçe, özet olarak şu işlevleri belirlemiştir:

1. Sosyo-kültürel bir değer, temelde seçici oryantasyonun standardıdır. Bu süreçte değer, bilinçli ve amaçlı davranışın genel kriteridir. Bir başka deyişle değer, eylemlerde bulunan bir kişinin kabul edilebilir arzu ve istekleri için bir referans noktası görevindedir.

2. Değerler, bir kültür içinde şekillenir ve aynı zamanda kültür üzerinde yönlendirici bir etkiye sahiptir. Diğer bir ifadeyle değerler, bir kültürün gelişme süreci içinde şekil almaktadir.

3. Değerler, insanlarla özdeşleşmiştir. Sosyalleşme sürecinde değerler, kişiler tarafından öğrenilmekte ve sahiplenilmektedir. Kısacası kişinin şahsiyet yapısına entegre olmaktadır. Bunun doğal bir sonucu olarak değerler, kişinin şahsiyetinin bir parçası olarak görülmektedir.

4. Değerler, bireyin hem zihinsel hem de duygusal yönünü yansitan ifadelerdir (Ulusoy ve Dilmaç 2012: 7-8).

\section{Menkıbe}

Osmanlıca-Türkçe lügatte menkıbe kelimesi "menkabe" olarak yer alır ve "çoğu tanınmış veya tarihe geçmiş kimselerin ahvaline (durumuna) ait fikralar, hikâyeler" (Devellioğlu 1992: 735) diye tanımlanır. "Menkıbeler; dinî şahsiyetlerin hayatlarında gösterdikleri kerametler, yaşantılarından sahneler, evrene bakışlarını içeren metinlerdir. Yapısal açıdan bakıldığında menkıbelerin öznesi kutsal kişilerdir. Menkıbe, velinin yaşamındaki her türlü halini anlatır. Dolayısıyla bazı metinler, velinin yardımseverliğini, cihat yapmasını vb. konu edinebilirler ve içlerinde keramet motifi barındırmazlar" (Pehlivan 2009: 91).

"Bir velinin kerametlerini anlatan kısa hikâyelere menkıbe denir. Bunlar, ilk önce tasavvufi tabakat (biyografi) kitaplarında ve evliya tezkirelerinde yer almıştır. Tek bir veli hakkındaki menkıbeleri toplayan eserlere ise menakıp, menakıpname ya da vilâyetname (velâyetname) adı verilir" (Ocak 2013: 25).

"Türk edebiyatı tarihinde menkıbe terimi, hikâye ve tarih anlamında da kullanılır" (Pehlivan 2009: 89). "Çeşitli araştırmalarda dinî şahsiyetler hakkındaki efsanelerin 'dinî efsaneler, velilerle ilgili efsaneler, keramet sahiplerinin efsaneleri, dinî binalarla ilgili efsaneler' adı altında tasnif edildikleri görülür" (Pehlivan 2009: 89).

"Menkıbe yahut menakıp, tasavvuf tarihinde sufilerin izhar ettikleri harikulade olaylar demek olan kerametleri nakleden küçük hikâyeler" (Ocak 2010: 27) olarak ortaya çımıştır. "Menkıbe, çok üniversal zamanları ve mekânları kapsayan bir olgudur 
ve özellikle dünya tarihini kapsayan büyük siyasal oluşumlarda onun çok önemli rolü vardır. Menkıbe, realiteye oturtulur, paralel olaylarla desteklenirse oluşumunu tamamlar. Milletlerin ve toplumların tarihinde hoş şeyler olarak ortaya çıkan menkıbeler, geniş kitleler üzerinde etkili olurlar. Modern çağlarda menkıbevi kişinin yerini karizmatik liderler almaktadır" (Ortaylı 2004: 12, 16, 18, 19, 22).

Menkıbeler, çoğunla dinî şahıslar ve onlara dair olaylarla ilgili anlatılan ve olağanüstü unsurlar taşımalarına rağmen inandırıcı olma özelliği olan çoğunlukla kısa anlatılardır. Türk kültür hayatının ürünleri olan menkıbeler, sosyal hayata ve insan ilişkilerine dair birçok bilgiyi barındırır. Menkıbelerde insan davranışlarının olumlu yönleri alkışlanırken olumsuz yönleri eleştirilir. Bu yönüyle menkıbeler, hayata çeki düzen verir. Menkıbelerde bir toplumun hayata bakış açısı, yaşam tarzı ve değer anlayışı, bir kurgusal olay ekseninde dinleyiciye aksettirilir. Halk nazarında bu kurgusal olay, gerçek olaymış gibi telakki edilerek tıpkı efsanelerde olduğu gibi inanç konusu haline getirilir. Menkıbe dinleyicisi, menkıbede anlatılan olaya inanır ve aksi durumun olumsuz sonuçlar doğurabileceğini düşünür. Menkıbeler, geniş halk kitlelerine öğretilmesi gereken bir konunun en kısa yoldan ve kalıcı olarak anlatılmasını sağlar. Bu bağlamda menkıbelerde halkı bilinçlendirmek esastır. Menkıbelerin genel çerçevesi dinî eğitimdir. Bu dinî eğitimin bir kısmının "değerler eğitimi” ekseninde geliştiği dikkati çeker. Menkıbede olay, vurgulanmak istenen ana düşünceye hizmet edecek şekilde kurgulanır, böylelikle halkın anlamakta güçlük çekeceği bir konuya açıklık kazandırılmış olur. Menkıbe dinleyicisi; metinden ders çıkarır, ögüt alır. Menkıbe, dinî inancın güçlenmesine yardım eder.

Menkıbelerde olumlu ve olumsuz modeller, genellikle bir arada verilir. Olumlu model, genellikle olayların belirleyicisi ve etkileyicisi olan dinî şahsiyettir. Olumsuz model ise dönemin dinî anlayışına, inanca ve geleneksel değerlere aykırı tutum içinde olan uyarılan veya cezalandırılan kişidir. Menkıbelerde olumlu ve olumsuz tip/tipler, keskin çizgilerle ayrılır. Burada olumlu tipin davranışının teşvik edilip örnek model gösterilmesi, olumsuz tipin davranışının ise engellenmesi amaçlanır. Menkıbedeki tiplerin iki ayrı uçta yer alması (olumlu, olumsuz), aynı zamanda menkıbedeki iletinin de keskin çizgilerle ortaya çıkarılmasına imkân sunar. Zıtlıklar; menkıbedeki mesajın ön plana çıkarılmasında, vurgunun yapilmasında önemlidir.

Dinî inanışın etkili bir şekilde sosyal hayatı yönlendirdiği Siirt'te; menkıbeler, gerek geçmişte gerekse günümüzde sosyal hayatın belirleyici güçlerinden biri olmuştur. Yörede dinî inanışların nesilden nesile aktarımı, bir edebî metin olarak menkıbelerle sağlanmaktadır. Menkıbelerin varlık nedeni dinî inançlardır. Bir başka deyişle menkıbeler; dinî inancın kesintisiz, kestirmeden ve çarpıcı bir anlatımla aktarılmasında kullanılan edebi metinlerdir. Menkıbe döneminin geçerli ve gerekli dinî inancının savunuculuğunu yapar. Dinî otoriteyi temsil eder. Menkıbenin görevi dinî inancın dışına çıkan, aykırı davranışta bulunan kişiyi eğitmektir. Menkıbede korkutma, cezalandırma, hayrete düşürtme esastır. Menkıbe gücünü bu özelliklerinden alır. Nasıl ki fikra sonlarında söylenen etkili bir söz, kişiyi aynı anda düşündürüp güldürüyorsa menkıbelerde de menkıbe kahramanı/kahramanlarının başına gelen ilginç olay/durum, dinleyicide benzer bir etki yaratır. Yalnız fikradaki gülme eyleminin yerini menkıbede üzüntü veya korku alır. Menkıbelerde fikradaki gibi güldürürken düşündürmek değil, 
kıssadan hisse aldırarak ya da "cezayı göstererek" düşündürmek söz konusudur. Dönemin olumsuzluklarını eleștiren menkıbelerde, olumsuz tutum ve davranış sergileyen kişi veya kişilerin cezalandırılması, dinleyici üzerinde "uyarıcı" bir etkiye sahiptir.

Bir toplumun benimsemiş olduğu değerler, o toplumun yapı taşlarını oluşturur. $\mathrm{O}$ toplumda yaşayan her bir birey, bu yapı taşlarını belirli ölçülerde benimser ve o yapı taşlarına yeni eklemelerde bulunur. Toplumun önder şahsiyetleri -ki bunlar, menkıbelerde dinî şahsiyetler olarak karşımıza çıkar- bu bağlamda önem taşır. Onların gerçek ya da hayal ürünü hayat hikâyeleri, toplumun yüzyıllar boyunca benimsemiş olduğu temel değerler ekseninde dile gelir. Bir dinîşahsiyetin hayatını aksettiren bir anlatı, o topluluğun benimsemiş olduğu bir dinî değere vurgu yapar. Anlatıda yapılan bu vurgu, çoğu kez geleneksel eğitim tarzının bir yansıması olan korkutma, cezalandırma veya öğüt/ders verme şeklinde ortaya çıar.

Menkıbeler, toplumun sahip olduğu değerlerle ilişkili olduğu gibi aynı zamanda bu değerlerin öğretiminde de bir araçtır. Günümüz toplumunda bilhassa informal eğitimde kullanılan menkıbelerle bireyin toplumun beklentisine uygun bir şekilde davranması sağlanmaya çalışılır. Aile içinde, kahvehanelerde veya muhtelif arkadaş toplantılarında söz konusu edilen menkıbelerle bireyin topluma uyumu ve sosyalleşmesi yolunda birtakım adımlar atılmış olur. Menkıbeler, sadece bireyin toplumsal süreçteki eğitimiyle ilgilenmez. Aynı zamanda bir toplumun sürekliliğinde de söz sahibidir. Menkıbe, bu işlevini bir topluluğa ait kültürel miras ürünü olmasıyla yerine getirir.

$\mathrm{Bu}$ araştırmada nitel araştırma yöntemlerinden metin inceleme yöntemi kullanılarak Siirt menkıbelerinde bulunan değerler tespit edilmiştir. Araştırmanın veri toplama kaynağını "Siirt Menkıbeleri ve Türbe Ritüelleri" adlı kitapta yer alan toplam doksan menkıbe oluşturmaktadır. Verilerin analizinde betimsel analiz yaklaşımı kullanılıışıır. Adı geçen kitapta yer alan menkıbeler Rokeach’n değer sınıflandırması dikkate alınarak incelenmiştir.

\section{Kendini kontrol edebilme (hakareti / alayı önlemek)}

İncelenen menkıbelerin dördünde yer alan "kendini kontrol edebilme" değerine hakaret etmemek, alayı önlemek gibi davranışlar örnek olarak yer verilir.

"Şeyh Ebubekir" menkıbesinde köyde bu şeyhe inanmayan Ömer adında bir kişiden söz edilir. "Ömer, arkadaşlarıyla bir gün türbe civarında dolaşırken türbe duvarına idrarını yapmış. Arkadaşları bir süre sonra Ömer’i göremeyince onu aramaya çıkmışlar. Onu türbenin arka bölümünde yere uzanmış bir şekilde görmüşler. Ömer, yerde ölü gibi yatıyormuş. Rivayetlere göre şeyh, onu cezalandırmış ve firlatıp atmış. Ömer; o günden sonra delirmiş, bir daha kendine gelememiş" (Karakaş 2010: 133). Kendini kontrol edemeyip bir din büyüğünün yattığı yere saygısızlık yapan Ömer, akıl sağlığını kaybeder. $\mathrm{Bu}$, bize menkıbenin verdiği derstir. Menkıbe kahramanının cezalandırılması, dinleyici için ibret alınması gereken bir olay olarak algılanır. Menkıbenin devamında "kendini kontrol etme" değerinin önemi, yine kendini kontrol edememiş olan Ömer adlı kahramanın sonu bağlamında şöyle aktarılır: "Aradan yıllar geçmiş; köylüler, bir zamanlar Ömer’in yattığ 1 yerde hiç çimen çıkmadığını ve onun vücudunun izinin çıktığını, aynı zamanda o kısma hiç kar yağmadığını hayretler içerisinde görmüşlerdir” (Karakaş 2014: 133). 
"Şeyh Ebubekir" menkıbesinde olduğu gibi "Şeyh Kal" adlı menkıbede de bir din büyüğünün türbesine saygısızlık yapacak kadar kendini kontrol edemeyen bir kişiden söz edilir. "Rivayetlere göre bir zamanlar türbe civarından geçen askerlerden birkaçı, 'Burada kim yatıyor da böyle güzel bir türbesi var!' diyerek şeyhle dalga geçerler; bazıları türbe duvarına abdest bozarlar. Halk arasında bu askerlerin akli dengelerini kaybettikleri, bir kısmının da oracıkta can verdiği anlatılır" (Karakaş 2014: 137). Kendini kontrol edememenin bir sonucu olarak ortaya çıan bu davranışta, doğa da yine kendine has tepkisini koyar. "Ölen askerlerden birkaçının fiziksel şekli olduğu düşünülen izler, türbe girişinde yer almaktadır. Türbe civarı yemyeşil olduğu halde, izlerin olduğu bölümde tek bir çim bulunmamaktadır” (Karakaş 2014: 137).

"Yeşil Işsk Şeyhi: Şeyh Halil Menkıbesi" adlı Siirt menkıbesinde kendini kontrol edemeyip şeyhlere, hakarete varan söylemler gerçekleştirildiğinde sonucun ne olacağ 1 şöyle vurgulanır: "Yeşil ışı şeyhinin namı büyüktür. Herhangi biri, onlara hakaret ederse bu şeyhler, derhal bu insanlara zarar verir. Yeşil ışık şeyhleri, bu tür insanların vücutlarının herhangi bir yerinde, küçük bir yara çıararak onları cezalandırır. Bu yara, devamlı kaşınır ve kaşındıkça da büyür” (Karakaş 2014: 137).

"Sultan Memduh 4" menkıbesinde, Sultan Memduh, Abdürrahim Efendi adlı müridiyle dergâhının önünde oturmaktadır. Bu sırada Sultan Memduh, kerameti sayesinde ona oldukça uzak bir mesafede bulunan Boşi köyünden bir görüntü gösterir. Görüntüde Sultan Memduhun talebeleri sohbet ederken köy bekçisi de onlarla alay etmektedir. Abdürrahim Efendi; Sultan’n izniyle bekçiye haddini bildirmek ister, Sultan müsaade edince de bekçiye kuvvetlice bir tekme savurur. On gün sonra bekçi, yüzü gözü eğrilmiş şekilde şifa bulmak için Sultan Memduh’a gelir” (Arslan 2006: 165).

"Kendini kontrol edebilme" değeri, üç menkıbede "hakaret etme" bir menkıbede ise "alay etme" davranışlarının önlenmesi kapsamında irdelenir. Dinî şahsiyetlere yönelik hakaret ve alay eylemleri, ağır cezalarla sonuçlanır. Akıl sağlığının yitirilmesi, felç olma, cilt rahatsızlığı gibi... Bu menkıbeleri dinleyen kişi, en azından bu tür trajik vakalarla karşılaşmamak adına da olsa dinî şahsiyete veya herhangi başka birine hakaret veya alay edici sözler söylememesi gerektiğinin bilincine varır.

\section{Geniş görüşlü olmak}

'Şeyh Hüseyin (Bapiro) Türbesi' adlı menkıbede aktarılan değer, ilginç bir olay örgüsüne sahiptir. Olay, bir beyin çevresine topladığı dervişlere felsefi bir yaklaşımla "Hayat nedir?" diye sormasıyla başlar. Dervişlerden biri "Yemek yemek ve onu çıkarmak." şeklinde oldukça ilginç bir cevap verir. Bey, bu cevabın arkasındaki manayı anlayamamış olacak ki "Benim huzurumda böyle konuşmaya nasıl cesaret edersin?" diye sorar. Dervişi cezalandırmak ister; ancak kendisi oldukça kötü bir rahatsızlığa yakalanır. Böylece bey, dervişin ne demek istediğini de anlamış olur. Menkıbe, ceza vermemek, anlayışlı olmak mesajları çerçevesinde geniş görüşlü olmak değerini okuyucuya aktarır.

"Şeyh Ali Fiskini 1" menkıbesinde üvey anne, karlı bir kış günü damdaki karları temizlemesi için Şeyh Ali'yi dama gönderir. Şeyh Ali’nin karı temizleyecek ve loğu çevirecek gücü yoktur. Ona bu işi yapması için iki yılan yardım eder. Üvey anne, dama çıkar ve yılanların Şeyh Ali’ye yardım ettiklerini görür. Böylece hatasını anlar. 
"Şeyh Ali Fiskini 2" adlı menkıbe, hem olay örgüsü hem de mesaj olarak birinci anlatı ile paralellik gösterir. Menkıbenin kahramanı yine Şeyh Ali ile üvey annesidir. Üvey anne, Şeyh Aliden kısa bir zaman içerisinde buğday çuvalını değirmene götürüp ögütmesini ister. Aksi halde onu öldürmekle tehdit eder. Şeyh Ali, üvey annesinden korkar ve buğdayları değirmene götürür. Ancak çok sıra vardır. Şeyh Ali yaşadığı sıkıntılı durumu, değirmenciye anlatır. Fakat değirmenci oralı olmaz. Şeyh Ali beddua eder ve değirmen yerle bir olur.

Her iki menkıbe de geniş görüşlü olmayan, anlayışsız bir üvey anne ekseninde gelişir. Menkıbeler, geniş görüşlü olunması gerektiğini olumsuz modellerden yola çıarak vurgular. Özellikle ikinci menkıbede değirmencinin üvey anne baskısı altında olan öksüz bir çocuğun ahvalini anlamaması üzerine karşılaştığı olumsuz olay (değirmeninin yıkılması), dinleyicide geniş görüşlü olmaya yönelik bir düşüncenin oluşmasına zemin hazırlar.

\section{Aile güvenliği}

"Amine Haciyo 2" menkıbesinde, ibadet etmek için sık sık göl kenarına giden Amino Haciyo, hem ailesi hem de kocasının ailesi tarafından gözetlenmektedir. Namaz kılarken selam verdiği sırada ailesinin kendisini gözetlediğini fark eden menkıbe kahramanı, bu duruma çok üzülür ve "Allahım! Babam tarafındakilerin hepsi kalpten gitsinler, kocam tarafının da soyları hiçbir zaman çoğalmasın. İki olsun üç olmasın, üç olsun dört olmasın." diyerek beddua eder. Böylece menkıbe, güvenirlik değerinin aile içerisinde ne kadar önemli olduğuna vurgu yapar.

\section{İtaatkâr olma (son arzu / vasiyet)}

"Şeyh Kâl (Babikal) 1" adlı menkıbenin kahramanı Şeyh Kal; yaklaşık yüz elli veya iki yüz yıl önce yaşamış, hem Nakşibendi hem de Kadiri tarikatının halifesidir. Eruh’un Bağgöze köyündeki Şeyh Kâl (Şeyh Babikal), vefatından önce köyün ileri gelenlerine kendisi için bir türbe yapılmasını ve başucuna da bir ağaç dikilmesini vasiyet eder. Şeyh Babikal, vefat ettikten sonra köylüler, bir türbe yaparlar ve hayvanların mezara zarar vermemesi için türbenin üstünü kapatırlar. Köylüler, sabah uyandıklarında türbe çatısının yerinde olmadığını görürler ve tekrar çatı yaparlar; ancak ertesi gün çatının yine yerinde olmadığını görürler. Tam üç kez tekrarlanan bu olaydan sonra köylüler, türbenin çatı kabul etmediğine kanaat getirirler. Aradan birkaç yıl geçtikten sonra mezarın ortasından bir ağaç çıkar. $\mathrm{Bu}$ ağaç, şu an adeta bir çatı gibi tüm mezarı kaplamaktadır” (Karakaş 2014: 137).

Bu menkıbenin farklı bir rivayeti Şeyh Hüseyin (Bapiro) için de anlatılır. Şeyh Kal'de olduğu gibi Şeyh Hüseyin'in türbesinin de üstü kapatılmak istenmiştir. Ancak her defasında türbenin tavanı çökmüştür. Olay üç kez tekrarlandıktan sonra Şeyh Hüseyin, insanların rüyasına girerek türbesinin üzerinin kapatılmasını istemediğini bildirmiştir. Bunun üzerine yöre halkı türbe üzerini açık bırakmıştır.

Şeyh Neccar, zikirlerini tef eşliğinde yapan dinî bir liderdir. Vefat ettiği zaman halk, 
cenazesini kaldırmak ister, fakat bir türlü yerinden kaldıramaz. Aile, şeyhin öldüğü vakit cenazesinin tef eşliğinde kaldırılmasını vasiyet ettiğini söyler. Bunun üzerine şeyhin müritleri tef eşliğinde gelip cenazeyi kaldırırlar" (Karakaş 2014: 142). Menkıbe, bu noktaya kadar vasiyete uygun davranmanın önemini aktarır. Menkıbenin devamında aynı değer, biraz daha ilginç bir hal alarak şu şekilde vurgulanır: "Cenaze namazı kılınır, ancak cenaze bu sefer de musalla taşından kalkmaz. Cemaat, şeyhin ikinci bir vasiyetinin olup olmadığını sorar. Aile 'hayır' diye karşılık verir. Akşama doğru Yemen'den şeyhin müridi olduğunu söyleyen bir kişi gelir. Bu mürit; şeyhin kendisine bir vakit, "Ben ölürsem cenaze namazımı sen kıldıracaksın” diye vasiyet ettiğini söyler. Böylece defin işlemi tamamlanır. Menkıbe boyunca "itaatkâr olma" değeri, din büyüğünün emrine itaat etme, vasiyetini her şartta yerine getirme şeklinde karşımıza çıar.

\section{İç huzur (emanet)}

"Amine Haciyo" adına anlatılan üç menkıbe bulunmaktadır. Bunlardan birinde Amine Haciyo, hacca gitmeye karar verir; ancak çocuğunu kime teslim edeceğini bilemez. Sonunda çocuğuna ancak Allahı̉n sahip çıkacağına kanaat getirir. Tevekkül ederek çocuğunu bir dağa teslim eder. Bir ceylan, dağda tek başına kalan yavruyu emzirir ve bir anne gibi ona bakar. Dağın yamacından esen rüzgâr, çocuğun salıncağını sallar. Hacdan dönen kadın, çocuğuna kavuşur. Anne ve çocuğu ölünceye kadar o dağda yaşarlar” (Karakaş 2014: 120). Menkıbe, bir annenin çocuğunu yaratıcısına emanet ederek iç huzura ulaşmasının anlatımında bir araç olarak kullanılmıştır.

\section{Özgürlük (ibadet özgürlüğü)}

Geçmişten günümüze “özgürlük” üzerine muhtelif düşünceler geliştirilmiştir. Çağımızın modern dünyasında dahi dil, din, düşünce, inanç, hukuk, eğitim gibi alanlarda özgürlük kavramı tartışılmaktadır. İnsanların tercihlerine saygı duymak, inandıklarını özgürce ifade edebilecekleri ortamı sağlamak ve inançları gereği yaptıkları pratiklerde serbest bırakmak evrensel bir değerdir. Bu değere zit bir tutum içerisinde olan bir kralın ibret verici sonu, değerin toplumumuza yerleşmesine yardımcı olabilir. Şöyle ki: "Şeyh Neccar, İslamiyet'i henüz kabul etmemiş olan Siirt'te Müslüman biri olarak yaşamaktadır. Şehrin kralı, Şeyh Neccar’n ibadet etmesini yasaklar. Bunun üzerine Şeyh Neccar, Siirt dışında bir oyukta gizlice ibadetlerini yapar. Derebeyi, Şeyh Neccar'ın ibadetlerine devam ettiğini öğrenir. Askerleri aracıllğıyla haber yollayarak ondan bir gece içerisinde yüz adet tabut yapmasını emreder. Aksi takdirde onu öldüreceğini söyler. Gece biter sabah olur, Şeyh Neccar bütün çabalarına rağmen yüz tabutu yapamamıştır. Askerler, kapısını çalar ve ondan gece ölen derebeyleri için bir adet tabut yapmasını isterler” (Karakaş 2014: 141).

İslamiyet hoşgörü dinidir. Kalplere hitap eden İslamiyet, ulaşttğı coğrafyalarda hiçbir kişiyi veya halkı kılıç zoruyla Müslüman yapmaya çalışmamıştır. Yukarıdaki menkıbede farklı dine mensup bir derebeyinin tahammülsüzlüğü ve hoşgörüsüzlüğü yansitılarak İslamiyet'in ve İslamiyet'i benimsemiş şahısların yüceliğine vurgu yapılmak istenmiştir. 


\section{Ruhsal temiz olma (namus vurgusu)}

"Benetıs Sıtra (İbleliye) 1" adlı menkıbede genç kızlar, yıkanmak için bir hamama giderler. Bu sırada oradan geçen askerler, hamama gelir ve kızlardan kapıyı açmalarını isterler. Eskiden çıplak haldeyken duaların daha çok kabul olacağına inanılırdı. Bu yüzden yedi kız, askerlerin içeri girememesi ve oldukları yerde hamamın yıkılıp kendilerinin de ölmesi için dua ederler. Allah, onların duasını kabul eder ve hamam yıkılır (Karakaş 2010: 120).

"Masum olduğu halde hapse atılan ve bir türlü suçsuzluğunu kanıtlayamayan Yusuf adlı biri, kendisini bu durumdan kurtarmaları için evliyaları yardıma çağırır. Sultan Memduh, Yusuf'un isteğine cevap verir ve ona 'haydi kalk yürü ve buradan çık' der. Kilitli kapı açılır, Yusuf evine gider. Bir daha da kimse onu arayıp sormaz" (Arslan 2006: 164, 165). Kilidin kendiliğinden açılması, Yusuf'un ruhsal açıdan temiz olması değerini sembolize etmesi bakımından dikkate değerdir.

Her iki menkıbede de masum ve ruhsal yönden temiz bireylerin kurtuluşu müjdelenir. Birinci menkıbede genç kızların namuslarına halel gelmeden ölmelerinin, ikinci menkıbede ise suçsuz birinin hapisten kurtuluşunun haberi dinleyiciye aktarılır.

\section{Barış içinde bir dünya}

Geçmişten günümüze tüm toplumlarda "barış içinde bir dünya özlemi"nin var olduğundan bahsedebiliriz. Dünya tarihinin muhtelif savaşlarla dolu olduğunu ve günümüzde özellikle az gelişmiş ülkelerde bu türden savaşların devam etmesi, "barış içinde bir dünyaya duyulan özlemi” pekiştirmektedir.

Toplumun huzur ve refah içinde olması, birçok bileşenin bir arada olmasıyla mümkündür. Örneğin bir toplumun adalet mekanizmasının güçlü, eğitim müesseselerinin çağın dinamiklerine uygun olması gibi. Sosyal hayat içinde ortaya çıkan bazı olaylar, toplumun huzurunu zedeler. Hırsızlık, bunlardan biridir ve suç kabul edilir. Buna rağmen bazı bireylerin bu suça yeltendikleri görülür. Hırsızlık, kişinin kendine ait olmayan bir mal veya eşyaya gizlice sahip olmasıdır. Hırsızlığın olduğu bir toplumda kişinin huzur ve güvenliği zedelenir. Çocuklar için yazılmış bazı hikâye ve romanlarda, efsanelerde veya menkıbelerde hırsızlık yapanların karşılaştı̆̆ı olumsuz durumları gösteren muhtelif örnekler mevcuttur.

İbrahim Hakkı için aktarılan Siirt menkıbesinde bir hırsızlık olayına değinilir. “İbrahim Hakkı, henüz küçük yaşta iken annesi, ona yıkayıp bahçeye astığı çamaşırlara dikkat etmesini söyler. İbrahim Hakkı bu görevi yerine getiremez. Hırsızın biri, ipe asılı bütün çamaşırları çalar. İbrahim Hakkı, annesinin 'Neden çamaşırlara dikkat etmedin?' sorusuna 'Merak etme anne, çamaşırlar bize aitse onlar geri gelirler' diyerek cevap verir. Hırsız, çaldığı elbiselerle nereye giderse gitsin karşısında İbrahim Hakkı'yı görür. Kaçacak yer bulamayınca da çamaşırları getirip geri verir" (Arslan 2006: 154).

"Şeyh Muhammet ve Kara Ev" adlı menkıbede şu olay aktarılır: "Kasımlı köyünün ağası ile Derzin köyünün ağası arasında geçmişten gelen bir husumet vardır. Derzin köyünün ağası, bir gün Kasımlı köyünün ağasının sürülerine zarar vermeleri için adamlarını yollar. Adamlar, sürüden birkaç keçi çalacaktır. Ancak adamlar, sürünün olduğu 
yere vardıklarında da hayvanların etrafının surlarla çevrili olduğunu görürler, surların etrafını dönerler, fakat bir türlü içeri girebilecekleri bir kapı bulamazlar. Ağa; adamlarına inanmaz, kendi gözleriyle gidip görmek ister. Fakat o da surlardan geçip keçilere ulaşamaz" (Karakaş 2014: 139).

Başkasının malına el koyma davranışı, toplumun huzurunu bozacağı ve birtakım çatışmalar oluşturacağı için barış içerisindeki bir dünyayı zedeler. Hırsızlıktan farklı olarak bu davranış açıktan da gerçekleştirilebilir. "Şeyh Neccar 1" adlı menkıbede başkasının malına el koymayı kendine hak gören bir hükümdarın sonu, bir ders olarak bu değerin topluma yerleşmesi ve pekişmesi için kullanılmıştır. "Merg adlı Siirt derebeyi, zalimliğiyle ün salmıştır. Zalimliklerinden biri de yeni evlenmiş bir erkekten eşini üç günlügüne almasıdır. Şeyh Neccar da bu durumla karşı karşıya kalır, fakat o, eşini derebeyine vermek istemez, ancak çaresizlik içerisindedir. Şeyhin annesi, onu 'Allah birdir, fakat çıar yol bindir' diyerek teselli eder. O gecenin sabahında derebeyinin askerleri, tekrar şeyhin kapısına gelirler. Şeyh Neccar, kapıyı korkuyla açar, askerler ondan gece yarısı ölen derebeyleri için bir tabut yapmasını istemeye gelmişlerdir” (Karakaş 2014: 139).

Kişiye hakkını vermek, başkasının hakkını yememek; toplumdaki adalet duygusunu güçlendireceği için bireylerin toplum kurallarına uymasını ve özellikle birbirlerine olan saygısının artmasını sağlar. Adalet mekanizmasını yerleştirebilmiş bu tarz bir toplumda, gerilim ve çatışmanın azalacağından söz edilebilir. Bu sayede toplum bireyleri, barış içindeki bir dünyaya bir adım daha yaklaşmış olurlar. İbrahim Hakkı̉nın karşı görüşlü bir dinin lideri olsa dahi kişiye hakkını teslim etmesi, menkıbede şu şekilde aktarılır: "İbrahim Hakkı ile bir papaz yanlarındaki bir ata dönüşümlü olarak binerek seyahat etmekte ve Erzurum'dan Tillo'ya doğru gitmektedirler. Murat suyu yakınlarına geldiklerinde ise papaz, İbrahim Hakkı'ya ata binmesini ve suyu geçmesini teklif eder. İbrahim Hakkı, ata binme sırası papazda olduğu için bu teklifi kabul etmez. Papaz, ata biner ve karşıya geçer" (Karakaş 2014: 123).

Yukarıdaki Siirt menkıbeleri, "adalet" kavramına vurgu yapar. Bu kavram, bazen "ilahi adalet" ekseninde ifadesini bulur. Bazen de adalet kavramının timsali dinî bir lider, evliya olarak gösterilir. Günümüz Türk halk kültüründe adaletin er geç telakki edeceği inanışı yaygındır. Bu inanış, Allah’a olan inanç ve güvenle ilişkilidir.

\section{Dinî olgunluk}

Halk arasında kişiler, yaptıkları işe, ailesine, kazandıklarına vb. kişilere göre tasnif edilir ve bazı sınıflara ayrılırlar. Bu bağlamda köylü, işçi, memur, ağa, seyit, zengin, fakir gibi birçok nitelendirme mevcuttur. Ancak İslamiyet’te kişi, ne olursa olsun öncelikle insandır ve Allah’a olan yakınlığı ve takvası ölçüsünde değerlendirilir. Aşağıdaki menkıbede toplumun üst sınıflarından birinde yer alan ağa ile onun tam zıttı bir pozisyondaki çobanın değeri üzerine bir yargıda bulunulur. Çobanın Allah nazarındaki değerinin çok daha üstün olduğuna vurgu yapılır:

"Şeyh Muhammet ve Kara Ev" adlı menkıbede, dinî olgunluğa erişerek çevresine kendini kanıtlamış bir şahsiyetin çevresi tarafından değer görmesi gerektiği, ağa aracılığıyla vurgulanır. Şöyle ki, "Ağa, çobanın keramet ehli biri olduğunu anlar ve ertesi gün, 
Kasımlı köyünün ağasının yanına giderek ona olan biteni anlatır. 'Senin çobanın senden de benden de üstün biri; onun çobanlık yapması, bizim için iyi sonuçlar doğurmaz' der.' (Karakaș 2014: 138).

$\mathrm{Bu}$ menkıbe, halk arasında yaygın bir şekilde ifade edilen "Para ile imanın kimde olduğu bilinmez." atasözünü de doğrulayacak niteliktedir.

\section{Bilgelik}

"Gusir Gölü Efsanesi ve Hızır” adlı menkıbede Hızır, kadına çocuğunu yanına alıp bu köyü terk etmesi tavsiyesinde bulunur. Yalnız tek bir şartı vardır, o da kesinlikle arkasına bakmamasıdır. Ancak kadın, çocuğuyla köyü terk ettiği sırada dayanamaz ve arkasına bakar. Kadın, Hızır’’n bu uyarısını dinlemediği için çocuğuyla taşa dönüşür.

"Şeyh Mahmut Bayraktar" adlı menkıbedeki dinî karizmatik lider Şeyh Mahmut, Halit Bin Velit döneminde yapılan bir savaşta başını kaybeder; ancak sancağı elinden bırakmamak için savaşmaya devam eder. Bunu gören bir kadın, dayanamayıp bu olağanüstü hadiseyi yanındakilere anlatınca Şeyh Mahmut oracıkta vefat eder" (Eryeşil 2001: 38).

"Şeyh Mücahit ve Hızır" adlı bir diğer Siirt menkıbesinde, "Akşam vakti çay yükselir, bu yüzden Şeyh, evine dönemez. Akşam namazını kılıp Allah’a dua eden şeyh, karşısında Hızır'ı görür. Hızır, ona 'Benden korkma, sana yardım edeceğim' der ve şeyhin elinden tutarak suyun üzerinden yürütüp karşı kıyıya geçirir. 'Sakın bunu kimseye anlatma!' diye de tembihte bulunur. Şeyh, evine gelir, ancak Hızır’nn söylediklerini unutur; başından geçenleri ailesiyle paylaşır. O akşam fenalaşan şeyh, sabaha doğru vefat eder” (Karakaş 2014: 141).

Sonuç olarak bilgelik değeri, Siirt menkıbelerinde sır saklamak ve veli uyarısına önem verip dikkate almak şeklinde kendini gösterir, diyebiliriz.

\section{Yardımseverlik}

"Yardımseverlik" değeri, Siirt menkıbelerinde ikramda bulunmak özelliğine vurgu yapılarak açıklanır. “Şeyhü’l Hazin’in oğlu Şeyh Şerafettin, bir komutan tarafından tutuklanacaktır. Siirtli bir asker ise Şeyh Şerafettin’in büyük bir âlim olduğunu söyleyerek tutuklama olayını engellemek ister. Bunun üzerine komutan, 'Bahsettiğin şeyh, gerçekten keramet sahibi ise onu tutuklamaya gittiğimiz vakit bizi, bu kış günü bal ve üzümle ağırlasın!' der. Şeyh, eğer bunu yaparsa onu tutuklamaktan vazgeçeceğine söz verir. Komutan ve asker, şeyhin yanına gider. Şeyh, komutanın canının bal ve üzüm çektiğini söyleyerek onlara bal ve üzüm ikramında bulunur. Bu olay üzerine komutan da şeyhe tabi olur" (Karakaş 2014: 144). Menkıbede, şeyhin tutuklanmaktan kurtulması ve yeni bir mürit kazanması, keramet göstererek ikramda bulunmasına ve karşılık beklemeden yardım yapmasına bağlıdır. Bu mesaj çerçevesinde okuyucu, yardımseverliğe yönlendirilebilir.

"Şeyh Hasan" adlı menkıbede, "Babasının keramet gücünü yitirmiş olduğu Şeyh Hasan’a malum olur. Şeyh Hasan, babasının diğer şeyhler yanında zor durumda kalması$\mathrm{n}$ istemez ve onun yerine sınava girmek ister." Bu sayede babasına yardımcı olur.

"Gusir Gölü Efsanesi ve Hızır" adlı anlatıda ise "Eruh’un Ormanardı köyüne giden ve kapı kapı dolaşan Hızır, bir yerde misafir olarak kalmak ister; ancak onu hiç kimse kabul 
etmez. Yalnız fakir bir kadın, ona kapısını açar. Hızır, kadından yiyecek bir şeyler ister. Ancak o, tencerede çocukları için kaynattığı taştan başka hiçbir şeyi olmadığını söyler (Karakaş 2014: 122).

"Hesta Kaplıcası 3" adlı menkıbede yardımseverlik değeri, Hz. Süleyman’ın hasta bir adamı sırtında taşıması şeklinde vurgulanır.

Aşağıdaki tabloda Siirt menkıbelerinde bulunan değerlerin frekans dağılımı verilmiştir.

\begin{tabular}{lcc}
\hline Değer Adları & Bulunma Sayısı & Değer Grubu \\
\hline Kendini Kontrol Edebilme & 4 & Vasıta \\
\hline Yardımseverlik & 4 & Vasıta \\
\hline Barış İçinde Bir Dünya & 3 & Gaye \\
\hline Bilgelik & 3 & Gaye \\
\hline Geniş Görüşlü Olmak & 3 & Vasıta \\
\hline İtaatkâr Olmak & 3 & Vasıta \\
\hline Aile Güvenliği & 1 & Gaye \\
\hline Dinî Olgunluk & 1 & Gaye \\
\hline İç Huzur & 1 & Gaye \\
\hline Özgürlük & 1 & Gaye \\
\hline Temiz Olmak & 1 & Vasıta \\
\hline
\end{tabular}

Tablo: Siirt Menkıbelerinde İşlenen Değerlerin Frekans Dağılımı

Tabloda en çok bulunan değerden en az bulunan değere doğru bir sıralama izlenmiştir. Kendini kontrol edebilme (4), Yardımseverlik (4), Barış içinde bir dünya (3), Bilgelik (3), Geniş görüşlü olmak (3), İtaatkâr olmak (3), Aile güvenliği (1), Dinî olgunluk (1), İç huzur (1), Özgürlük (1), Temiz olmak (1). İşlevsel halk bilimi kuramının önemli temsilcilerinden W. Bascom, folklorun işlevlerinden birisinin de sosyal değerleri, inanışları ve kurumları desteklemek olduğunu söyler. Siirt menkıbelerinde en çok işlenen değerin, vasıta değerlerden "kendini kontrol edebilme" olması, menkıbelerin sosyal değerleri desteklemesine uygun bir örnektir.

\section{Sonuç}

Doksan adet Siirt menkıbesini Rokeach’n değer sınıflandırması merkezinde incelediğimiz çalışmamızda bulunan değer grupları, nicel olarak hemen hemen birbirine yakındır. On beş menkıbede "vasıta değerler" işlenirken, on üçünde "gaye değerler" işlenir. Bununla birlikte bazı menkıbelerin bir değeri aktarmaktan ziyade olay örgüsüne bağlı bir mucize vurgusu yaptığı görülür.

Okuyucu/dinleyici, günlük hayatında evliyanın veya şeyhin davranışlarını taklit ederek onların davranışlarını kendi davranışlarıyla birleştirmeye çalışır. Bu sayede 
kişi, yeni davranış şekilleri ve buna paralel olarak yeni değerler de oluşturabilir. Elbette etkilenme derecesi, kişiden kişiye farklı olacaktır. Fakat bu, böyle bir etkilenmenin olabileceği gerçeğini ortadan kaldırmaz. Kısaca değerler, bir bütünü oluşturan parçalardır. Dolayısıyla bütün halinde kültürel varlığı devam ettirebilmek, bu değerlerin aktarımına bağlıdır.

Menkıbelerde anlatılan olayların gerçekten yaşanmış olarak telakki edilmesi, toplumsal değerlerin gelecek nesillere öğretilmesi noktasında önem taşır. İslamiyet'i benimsemiş dinleyici/dinleyiciler üzerinde dinî liderin yaşam öyküsüne ait varsayılan bir anlatı, sıradan bir anlatıya göre daha tesirli olacaktır.

Siirt menkıbelerinde olumlu ve olumsuz tipler çoğu zaman bir arada verilir. Olumlu tip, dini temsil eden şeyh, veli veya evliyadır. Olumsuz tip ise çoğu kez sıradan halktan olan şahıs/şahıslardır. Menkıbelerde bu iki zıt tip arasında yaşanan kısa ve vurgulayıcı bir olay anlatılır. Olaylar, adeta "Bin nasihatten bir musibet yeğdir" sözünü doğrularcasına kurgulanır. Neticede menkıbe, bir anlamda masallarda olduğu gibi iyiliğin, güzelliğin, hoşgörünün ve adaletin önemine vurgu yapan bir sonla tamamlanır. Böylece menkıbe, ait olduğu toplumun değer anlayışını gelecek nesillere iletme görevini üstlenmiş olur.

Siirt menkıbeleri kapsamında ele alınan bu çalışmanın Türk halk kültüründeki diğer menkıbelere yönelik olarak da yapılması gerekmektedir. Bu sayede değer eğitiminde kullanılabilecek daha fazla menkıbeye ulaşmak mümkün olacaktır. Sözlü eserlerin yerini yazılı eserlere bıraktığı, yazılı eserlerin ise yerini "e-eser" lere bırakmaya başladığ 1 günümüz dünyasında dinî inançların, geleneklerin, göreneklerin, ritüellerin, ziyaretlerin vb. nedenini açıklayan ve birtakım değerleri irdeleyen menkıbelerin korunması, kültür erozyonunu önlemek noktasında da ayrıca önemlidir. Bu bağlamda mayasını toplumun değer anlayışından alan menkıbeler; sosyal medya ortamlarında fotoğraf, video, karikatür, resim gibi görseller olarak paylaşılabileceği gibi, 12 yıllık eğitimin farklı süreçlerinde ders veya kaynak kitaplarında da yer alabilir.

\section{Kaynakça}

Aktürk, F. G. (2012) Çocukta değerler eğitimi açısından Üzeyir Gündüz ün eserleri, Basılmamış Yüksek Lisans Tezi, Afyon Kocatepe Üniversitesi, Sosyal Bilimler Enstitüsü, Afyonkarahisar.

Arslan, H. (2006) Yüksek ruhlar ve aydınlar yurdu Tillo, İstanbul. Simurg .

Devellioğlu, F. (1992) Osmanlıca-Türkçe ansiklopedik lugat, Ankara. Feryal.

Eryeşil, T. (2001) Siirt evliyaları ve menkıbeleri, Afyon Kocatepe Üniversitesi, Fen Edebiyat Fakültesi, Türk Dili ve Edebiyatı Bölümü, Bitirme Tezi, Danışman: Hayrettin Rayman, Afyon.

Güler, İ. M. (2015) Değerler eğitimi açısından Lütfiyye-i Vehbi, Atatürk Üniversitesi Eğitim Bilimleri Enstitüsü, Yayınlanmamış Yüksek Lisans Tezi. Erzurum.

Güven, A. Z. (2014) Türk efsanelerinin değerler eğitimi bakımından incelenmesi, Mustafa

Kemal Üniversitesi Sosyal Bilimler Dergisi, 11 (26), 225-246.

Karakaş, R. (2014) Siirt menkıbeleri ve türbe ritüelleri, Ankara. Maya.

Kaymakcan, R. (2010) Değer kavramı ve gençlerin dinî değerleri. Eğitime Bakış, s. 10-15. 
Ocak, A. Y. (2010) Kültür tarihi kaynağı olarak menâkıbnâmeler (Metodolojik bir yaklaşım), Ankara. Türk Tarih Kurumu.

Ocak, A. Y. (2013) Alevî ve Bektaşî inançlarının İslâm öncesi temelleri, İstanbul. İletişim.

Ortaylı, İ. (2004) Osmanlı Devletinin kuruluşu efsaneler ve gerçekler, Panel Bildirileri. Sayfa: (11-23). Ankara. İmge.

Özbay, M. (2002) Kültür aktarımı açısından Türkçe öğretimi. Sayı: 602, sayfa: (112-120). Türk Dili,

Pehlivan, G. (2009) Dinî şahsiyetler hakkında oluşan anlatılar. Millî Folklor, Cilt: 11, Y1l: 21, Say1: 83, Sayfa: (88-96).

Şen, Ü. (2007) Millî Eğitim Bakanlığı'nın 2005 yılında tavsiye ettiği 100 temel eser yoluyla Türkçe eğitiminde değerler öğretimi üzerine bir araştırma, Gazi Üniversitesi Eğitim Bilimleri Enstitüsü, Ankara.

TDK Türkçe Sözlük (2005) Ankara. Türk Dil Kurumu.

Ulusoy, K.; Dilmaç, B. (2012) Değerler eğitimi, Ankara. Pegem Akademi.

Uyanık B. G. (2012) Okul öncesinde değerler eğitimi, (Ed. Gülden Uyanık Balat), Okul Öncesinde Değerler Eğitimi ve Etkinlik Örnekleri, Ankara. Pegem Akademi. 